\title{
Doba and Ephemeral Durability: The Enduring Material Value of Women's Work in the Trobriand Regenerative Economy
}

\author{
Katherine Lepani
}

In the matrilineal Trobriand Islands, the intrinsic social value of sustaining interclan exchange relations and regenerating clan and dala (lineage) identity is invested largely in the productive work of sagali, or mortuary feasts. Organised and conducted primarily by women, the continued vitality of sagali is a significant measure of Trobriand cultural resilience in interaction with the material effects of modernity and the increasing commodification of exchange practices. The changing materiality of the Trobriand gift economy over the last several generations, marked by the incorporation of cash and commercial commodities, in particular manufactured cloth, has produced an efflorescence of new forms of exchange (Gregory 1982, 2015). Yet this dynamic process has not supplanted the value of doba-the banana fibre skirts and the bundles of dried banana leaves made by Trobriand women, which continue to comprise the central transactions in sagali. Distributed by the thousands during sagali events, the ephemeral banana leaf bundles retain centre stage in signifying the aesthetic and material worth of women's work in the regeneration of matrilineal identity. The durability of doba as both the subject and object of women's labour in mortuary distributions- 
activating relationality between persons and between persons and thingsheralds the enduring value of this particular form of gendered agency in the collective project of social reproduction.

Banana leaf bundles and fibre skirts have a modern equivalent; cloth, or karekwa after the English 'calico', has been fully integrated into sagali over the last several generations. Purchased from shops or acquired through elaborate networks of obligatory exchange, karekwa augments doba transactions in a number of forms-by the bolt, cut into 2-metre lengths, or sewn into skirts, blouses, shirts and pillow slips. The commensurability of pieces of cloth with banana leaf bundles and fibre skirts raises the question of the inevitable replacement of one form for the other through the increasing commodification of sagali. In this chapter, I explore the durability of doba in terms of form and value in relation to the escalated incorporation of cloth, cash and commodities into exchange relations, and what these reconfigurations signal about the work of women in the Trobriand regenerative economy.

\section{Material transformations}

The reconfiguration of doba over time reflects the deep sedimentation of Christianity in Trobriand cultural aesthetics and embodied practices, and speaks of the broader history of cloth as the icon of Christian conversion in the Pacific and the missionary vision of domesticity, gendered bodies and women's work (Jolly 2014: 3). In the early years of the twentieth century, Trobriand women first began cultivating their relational craft with karekwa at Oiabia, the Methodist Mission Station on the south coast of Kiriwina, by learning how to sew garments on Singer hand machines under the watchful eyes of expatriate missionaries (Akerman 2001: 5, 10). Paradoxically, Trobriand women were at once subject to the 1906 law of the Australian Territory of Papua, which prohibited Papuans from wearing cloth garments on the upper body (Connelly 2007: 70-71), while at the same time the skirts and blouses they crafted in mission station sewing classes were presented to visiting government officials as evidence of the 'tremendous force' the missionaries were having on transforming the moral bearing of the islanders (Akerman 2001: 41). The enterprise not only introduced new forms of gendered labour in the fashioning of Christian identity but it also marked emerging economic distinctions in the colonial landscape between Trobrianders residing within the moral boundaries of the mission station and villagers beyond (see Connelly 2007: 143). 
According to an elderly woman from Orabesi village (aged 84 at time of interview in 2000), the initial incorporation of cloth skirts and pieces of fabric into doba distributions dates back to the 1920s, in the context of a general prohibition of the practice of sagali on the Oiabia mission station. It seems that the innovation was approved by the missionaries as a truncated form of traditional funeral rites in response to the death of a Trobriand man on the mission station.

The time they started using clothes and materials [for sagali] we were still young ... At the time they didn't use doba on the mission station. There was a death on the station and the clans had to go together to look for new clothes and some foods ... they went together and they searched for materials and foods and money and they cooked food with chicken. At that time they were wearing black because of mourning so then they got rid of the black clothes and they got a bit of colour with the materials and new clothes. The sagali was just for those on the mission station. The European missionaries gave permission. My father's younger brother was the one who died. He died at the mission station so we had to make sagali. It wasn't like these days or before. We just had to do what we could on the station (Recorded interview, 20 December 2000).

Not allowed to invest their time and labour into the manufacture of banana leaf bundles, the first generation of Trobriand women living on the station also redirected the products of their sewing labour toward sagali distributions beyond the coral stone fence, which marked the mission boundaries. This deliberate transformation of the industriousness of Christian domesticity into a valued Trobriand form of embodied practice was dialectical. Similar to the early missionary encounters among the Suau people, also of the Milne Bay region in Papua New Guinea, Trobriand women discerned 'an image of themselves in the actions of the missionaries' (Demian 2007: 103), recognising their own valued capacities for doba production in the work of sewing. The materiality of form was also commensurate: measured lengths of karekwa and sewn skirts retained the value of women's work in sustaining interclan relations and reproducing matrilineal identity through mortuary exchange. Putting karekwa into circulation beyond the mission station no doubt carried new value as well-the image of Christian modernity and the material practicality of cotton-and forged new connections and transactional relationships in the elaborate networks of exchange linked to sagali distributions. 
The relationality performed by these women through the sewing of garments and the exchange of pieces of karekwa undoubtedly expressed their Christian faith, or tapwaroru, as well. A letter to the Australasian Methodist Missionary Review in 1893, written by William Bromilow, the founder of the Methodist mission in British New Guinea, contains an account by Bromilow's wife that indicates the value with which cloth was assessed by Christian converts. In the letter, Lily Bromilow describes the catechism she imparted during sewing classes at the Methodist mission headquarters on Dobu Island, part of the D'Entrecasteaux Islands in Milne Bay with close cultural and historical ties to the Trobriands. In response to the missionary's instructive question, 'What is taparoro'? (Dobu language for Christian faith), a young Dobu girl said, 'Taparoro is the calico we put on'. The missionary corrected her, saying, 'Taparoro is not calico or anything that we use; but Jesus in your heart' (Bromilow 1893: 6). ${ }^{1}$ I would suggest that the young girl's metonymic answer was likely misapprehended by the missionary, and that instead it was a direct expression of the perceived consonance between Christian faith and the value of relationality that productive labour, like sewing, makes visible. Similarly, in the Trobriands, calico as emblematic of Christian materiality resonates strongly with the enduring relational value of doba in gift exchange.

The initial material transformation of banana leaf bundles into cloth on the Oiabia mission station weaves through a deeper history of doba production. This is evidenced from the journal of Ethel Prisk, an Australian Methodist missionary whose six years in the Trobriands, from 1911 to 1916, overlapped with that of Bronisław Malinowski's period of ethnographic fieldwork. Prisk recorded the vernacular names and provided descriptions of 16 distinct types of banana, pandanus and coconut fibre skirts made for sagali (Prisk 1937). Considered in relation to Annette Weiner's pivotal ethnography on the status of women in Trobriand society (1976), which triggered debate about historical change and Malinowski's seemingly androcentric disregard of the central role of Trobriand women in mortuary distributions (see Jolly 1992; Strathern 1981), the evidence in Prisk's diary suggests that the woman missionary was more attentive than the male anthropologist when it came to contemporaneous observations of women's material culture (but see Bashkow 2011). The missionary women

1 I wish to acknowledge Ryan Schram for bringing this archival account to my attention, and for sharing with me his insights about missionaries' semiotic ideologies and the use of constructed dialogue in missionary records. 
admired the methods and skills involved in weaving fibre skirts, and on at least one occasion they organised a demonstration of doba manufacture for Malinowski when he visited the mission station (Young 2004: 399). The remarkable array of different skirt types that Prisk encountered in the early twentieth century no longer exists today. However, creativity in design continues to flourish, and no two fibre skirts are ever identical but rather they carry unique stylistic signatures of the individual makers. The diminished quantity of form may provide a firm measure of historical change regarding the displacement of banana fibre for cloth in the skirts that women make, yet it does not account for the enduring value of doba in the Trobriand exchange economy.

\section{Moral revaluations}

Questions surrounding the durability of doba across time came to the fore in a circumstantial event recounted to me by Diana, one of three Trobriand women who collaborated with me on my ethnographic research on culture and HIV in 2003 (Lepani 2012). Late one Saturday evening in August that year, after an all-day sagali at Kavataria-one of the largest villages in the Trobriands with a population of over 1,000 people, and located next to Oiabia mission station-a sudden downpour caught a group of women as they were about to set off to their home village on the northern side of Kiriwina Island. The women rushed to take shelter under the thatched roof of a communal seating platform on the church grounds, setting down the large baskets they were carrying on their heads, each replete with the doba they had received in sagali distributions. Dark clouds were rolling in the night sky and the rain did not look like it would let up anytime soon. Assessing the situation, the women called out to Diana's husband, David, who managed the church canteen, and asked him if they could store their doba baskets in the cement brick building until morning. The women did not mind getting wet walking the two hours to their village in the rain, but they did not want their doba to get wet. Rain-drenched bundles are rendered useless. Diana said that David quietly scoffed at their request:

Why should we look after their doba for the night? That's their problem, if they want to walk around with doba on their heads. Why are they wasting their time? They should be at home cooking for their families. 
But the women's request was not contestable; the resplendent baskets were sheltered overnight on the dry concrete floor of the church canteen.

David's assessment about the value of doba in terms of women's labour and investment of time echoes the views of Joshua, the young Trobriand man who would sometimes drive Weiner around Kiriwina in the vehicle belonging to the district health centre during her period of fieldwork in the early 1970s (Weiner 1980). Joshua had recently returned home to the Trobriands to take up a nursing position at the health centre after living and working elsewhere in Papua New Guinea. Weiner recounts how during one road trip when they happened to drive by a sagali in progress off the main road, Joshua remarked to her that doba bundles were useless and a drain on other resources, particularly hard-earned money.

We have to get those women to stop throwing their wealth, because they take our money. If the women would stop needing so many baskets of wealth ... then men would have plenty of money to pay for other things (Weiner 1980: 274).

Weiner inferred that Joshua's years living away from home and earning a wage income had caused him to revaluate doba in strictly 'Western capitalist terms', and she extended Joshua's comments with the proposition that doba as 'women's wealth' diminishes men's economic power (Weiner 1980: 273-74; but see Jolly 1992).

I have heard similar statements from women as well as men about the uselessness of doba as an exchange object and the extravagance of sagali as a social enterprise that diverts women away from more appropriate forms of work, like 'cooking for their families' (see also MacCarthy this volume). Banana leaf bundles are mere flimsy bits of fibre that get wet in the rain, take up storage space in large baskets in the recesses of small dwellings, turn musty and attract rats and cockroaches. The demands of doba manufacture, accumulation and storage in preparation for sagali are revaluated as disproportionate and wasteful in relation to the utility of commodity transactions. But I have also witnessed men helping women do the work of doba manufacture-scraping the strips of freshly cut banana leaves on incised kaidawagu boards and refreshing old bundles by pressing them with their hands. Men also channel substantial monetary resources into the work of sagali, supporting their wives and sisters to acquire bolts of material and purchasing trade-store food in bulk to augment men's sagali distributions of yams, taro, betel nut and pigs with 
rice, flour, sugar, tea and tin fish. Doba transactions correspond with the value of men's productive labour in yam cultivation and their complex networks of exchange (Weiner 1976), and the strength of men's exchange relations in the monetary economy-the ability to mobilise cash resources through obligatory ties (see Lepani 2012: 51-54).

Pieces of fabric are integral exchange items for sagali, which both replicate doba in form and value and supplement prime doba distributions (Figure 1). At present, there is no clear indication that fabric will eclipse banana leaf bundles as the preferred object of exchange. ${ }^{2}$ The extent to which the incorporation of cloth and cash has put new and potentially unsustainable financial pressures on the stability of sagali is the topic of much contemplation and debate by Trobrianders: amongst themselves in the planning stages of an upcoming sagali; in rhetoric emanating from the church pulpit and expressed at community meetings - with resonances of the Protestant work ethic of Methodism; and in reflective dialogue with the circulating discourses in Papua New Guinea on economic development and the commoditisation of customary practices. The analogy between yams and fortnightly wages has long shaped evaluations of men's obligatory contributions in the gift economy. Likewise, the correlation between doba and cloth in sagali distributions, aesthetically and pragmatically, has set new monetary measures of exchange. Bundles themselves are sometimes ascribed a currency value in comparison with cash, and in sagali transactions they represent the most immediate equivalence of form with the metric system of accounting, where individual distributions are made in units of five bundles. A man in his 40s told me, 'Money is part of custom now. Everything is money now. It would be hard to sagali without money. We need money for doba' (Journal notes, 9 October 2003). Women and men express ambivalence about the 'burden' of sagali, both financially and productively, but they also say they cannot 'give it up' because 'sagali keeps calling us'.

2 It is important to note the geographical variation of local practices in the Trobriand group of islands. Sagali practices on the outer islands, including Vakuta, Kitava and Kuyawa, do not involve the manufacture and distribution of banana leaf bundles like on the main island of Kiriwina. The diffusion and diversity of practice in such a critical element of Trobriand material culture necessarily reflects local political and historical interactions and processes, including that of broader trade networks and Christian missionisation. 


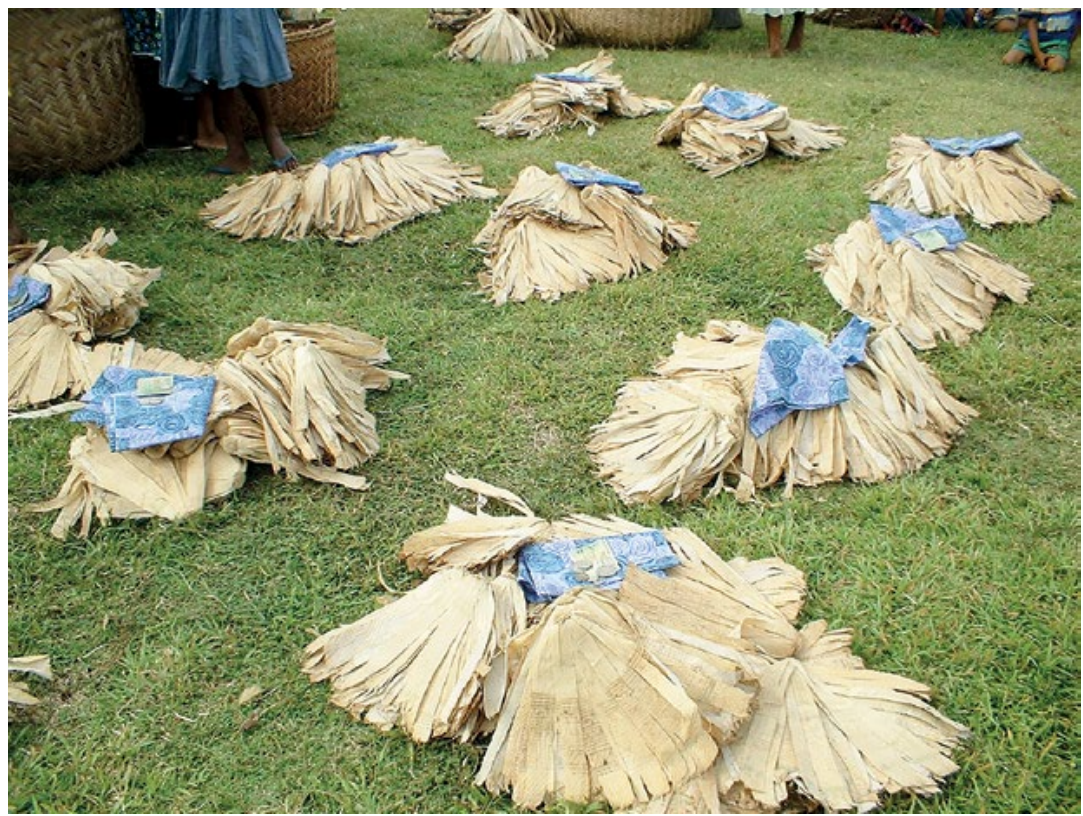

Figure 1. Complementary values: doba, cloth, cash, Orabesi village, Kiriwina

Source. Photographed by Katherine Lepani, 12 June 2003

Most Trobrianders, men and women alike, cannot imagine dealing with death without working for sagali, and many people say it would be impossible to do sagali properly without banana leaf bundles. While sagali practices on the outer islands of the Trobriand group do not involve distributions of banana leaf bundles, people from these islands nonetheless acknowledge the value of $d o b a$, and women who participate in sagali on Kiriwina also receive doba bundles and then recycle them through their interisland exchange networks. To an important extent, the continued use of bundles is a measure of limited access to monetary resources in the local economy. One needs money to purchase bolts of fabric. By contrast, bundles are not used in sagali distributions in urban contexts for equally pragmatic reasons. Urban residents engaged in wage labour do not have the time or requisite supply of banana trees in amounts sufficient for doba production, and whereas yams, clay pots, fibre skirts and woven mats and baskets are routinely transported as cargo by sea or air from the islands to urban centres for use in sagali, it would be an impractical folly to transport the ephemeral pieces of doba over such distances. 
About 20 years ago, a village on Kiriwina made the collective decision to give up sagali because it was viewed as too expensive and a wasteful preoccupation that kept people from other more important activities (see MacCarthy this volume). Despite this internal restriction, women and men from the village continue to attend and partake in sagali at other villages through their clan affiliations. Some women even redefined their relational position as entrepreneurs, producing and supplying woven mats and baskets as cash commodities for purchase by others to use in the hallmark sepwana and deli distributions (described below). The decision to cease sagali practice within the village has affected how young girls from the village view their marriage options. As one woman explained to me, 'Our girls don't want to marry here because no sagali. They want to marry other places so they can go there and sagali' (Group interview, 23 July 2003). The prospect of such diminished capacity in the moral economy of sagali suggests that, for women at least, the value of doba has not been displaced by frugal revaluations or commodity markets but continues to inhere in women's embodied contributions to the social reproduction of Trobriand values.

Joshua's statement to Weiner signalled the economic tensions affecting sagali, which have become more pronounced 40 years on, but I am curious whether he actually used the word 'wealth' to refer to doba. Trobrianders do not talk of doba as 'women's wealth', a decidedly anthropological term. The women I've asked about this descriptor find it a laughable fiction in translation: 'Oh, yes, we are very wealthy!' they exclaim with ironic humour. Clearly, their estimations are based on a notion of monetary affluence as conveyed by the English definition, in contrast to Weiner's conceptual use of the term 'women's wealth' to theorise the 'value of womanness' (1976: 230). The Trobriand word na'esaesa (na: female prefix; esaesa wealth) evokes wealth not in terms of acquired bounty but in the relational capacity to generate and redistribute objects of exchange. 'Valuable' is accepted by my interlocutors as an apt English word to qualify the importance of doba, yet it does not translate directly either. The Trobriand word for valuable, veguwau, classifies those exchange items that generally remain concealed until displayed and put into circulation (clay pots, stone axe blades, shell arm bands and necklaces); doba is not referred to as a valuable in this way. Nor do banana leaf bundles have commercial value in the monetary economy beyond the enterprise of sagali. Unlike woven mats and baskets, and banana fibre skirts to a lesser extent, doba bundles do not circulate beyond the Trobriands as valued exchange objects, nor do they convert to commodities for sale in the larger market place. 
Trobriand women quite simply refer to doba as paisewa, or work. Paisewa also refers to staging and partaking in sagali, and to the act of mourningobserving food taboos, wearing black clothing, restricting activities. In this distinctive sense, value-both cultural and economic-is located not in the objects of exchange but in embodied practice. Work is valued for its performative effects on a continuum of purpose in the production and exchange of goods. Objects are imbued with the value of productivity and performativity, always oriented towards working with others in mind. Work produces and makes visible social relations; hence, the value of objects cannot be assessed separately from the relations activated through exchange. Valuation involves a dialectical process in which personhood embodies the reproductive value of lineage, clan identity and attachments to place, and is projected onto objects of exchange. Likewise, objects of exchange and their transactions are imbued with personhood and the value of clan identity within embodied contexts of action.

The imperative to work for doba, and in so doing to demonstrate the capacity and fitness of one's matriline, accounts for the endurance of sagali in Trobriand social life. The materiality of doba is patent and ever present in the Trobriand landscape, and is striking to the most casual observer. Women cut and scrape banana leaves on the incised kaidawagu boards to remove the outer layer of skin and create textured patterns on the thin green strips. Along pathways and beside dwellings, the imprinted strips lie in straight rows on the ground, bleaching in the sun, turning light beige. Women work alone on a beach, or sit in groups in patches of shade, busily tying strips by the hundreds into fresh doba bundles. Women with enormous baskets of doba balanced on their heads, walk purposively to sagali (Figure 2).

The death of a clansperson sets in motion the work of sagali; women commence making and accumulating bundles, acquiring bolts of material and sewing skirts. For women to produce and acquire doba when not working towards a specific sagali would be unthinkable and diminish the value of their labour. Likewise, to hoard doba would be shameful. As the preparatory work of sagali unfolds, women receive contributions of doba from their in-laws and friends, and they take careful note of who supports them since these people will be recipients of doba and food distributions in the upcoming sagali. 


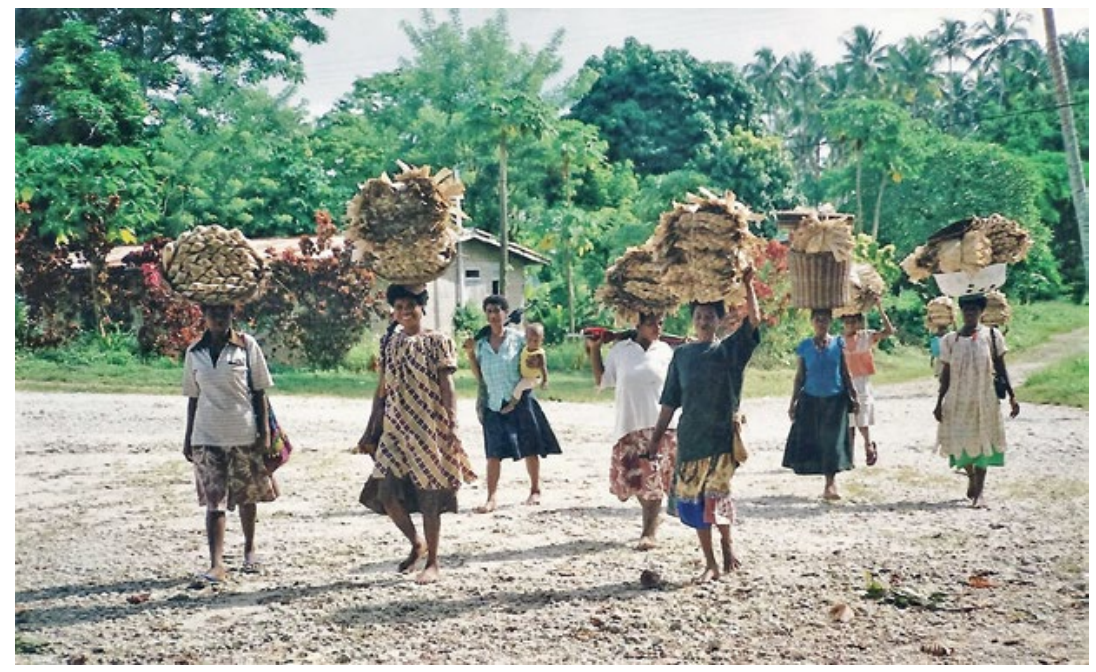

Figure 2. Women carrying baskets of doba, Losuia, Kiriwina

Source. Photographed by Katherine Lepani, 15 January 2000

Small transactions involving the exchange of various commodities for doba bundles-food items, firewood, kerosene and betel nut-become a daily occurrence as women work to build up their doba reserves. Called valova, these exchanges demonstrate the convertibility of doba as a unit of value (see MacCarthy this volume). Women will also purchase small items from the store-lollies, balloons, biscuits, tobacco-to exchange for doba. Valova transactions are one way that men become directly involved in supporting their mothers, sisters and wives with commodities and cash to acquire doba - an obligation subjected to moral evaluations, as conveyed by Joshua in his assessment of how sagali depletes men's monetary resources. However, the convertibility of cash for doba is strictly determined. Women would never make bundles as a commodity for monetary gain. Women valova to build their supply of doba, not to get rid of it; transactions are driven by a demand for doba, not a demand for cash. The only direct transaction involving cash for doba takes a very specific form-activating support through the village church by giving a cash donation to the women's fellowship group. In this way, a woman appeals to members of her church congregation to reciprocate collectively with a commensurate amount of doba as an obligatory contribution to support her work towards sagali. 
Trobrianders tend to speak of the process of accumulating doba by using the verb nene, meaning 'to search'. The idiom 'searching for doba' suggests that productivity is inherently social and not something achieved in isolation of other people's efforts. The valuation of doba is more than the product of its labour; it reflects the effort that goes into mobilising resources through social networks of exchange. The search for doba often involves mobility beyond the islands. Men sometimes will give their reason for travelling to Alotau, the provincial capital, or to Port Moresby as 'looking for doba' to help their mothers or wives with the work of sagali. The doba they find are not banana leaf bundles, but bolts of fabric purchased at shops with money earned through wage labour or acquired by activating exchange relationships with people who have sources of cash income.

At times, the work of sagali seems perpetual and all consuming. I recall many times when my late mother-in-law would sigh with resignation while busily preparing for a feast, and utter under her breath, 'Sagali, sagali, sagali. Her sighs were tinged with ambivalent affection as she smoothed the neatly arranged doba bundles and patted the growing pile of folded pieces of cloth, momentarily pausing from her work to lean back against the wall and chew betel nut. In 2000, in preparation for the sagali for her deceased maternal uncle, the last clan member of his generation to pass away, my mother-in-law was intensely involved in sewing skirts and dresses. Her personal doba inventory included a huge basket measuring 2 metres in circumference and 1 metre in height, which contained hundreds of banana leaf bundles. In addition, she had eight fibre skirts, 40 cotton skirts, 22 cotton dresses, 20 pillow cases, six bolts of material that were cut into 2-metre lengths for distribution, and four cotton skirts made specifically for sepwana (see below). The heightened daily comings and goings of women at the house, bringing small contributions of doba and bits of material to support my mother-in-law's efforts, put in motion a domestic rhythm that intensified as the day of sagali drew closer. My mother-in-law kept close account of those who supported her, and recorded names of contributors and the items they gave on a sheet of paper she kept between the pages of her Bible. At the end of the sagali, she was exuberant with exhaustion. With careful planning and auditing, her ample distributions were comprehensive and received with satisfaction. With her doba supplies now fully depleted, nothing left ungiven, she was indeed na'esaesa, a woman of wealth. 
Weiner underplays the incorporation of cloth into sagali even though it was well established during the time of her fieldwork in the mid-1970s. Cloth is not simply a substitute for bundles imposed by urban wage earners returning home to the islands, as Weiner infers from Joshua's comments, nor is cloth used by 'women who have been too lazy' to make bundles (1976: 113). Such moral revaluations fail to recognise the complementarity of form between banana leaf bundles and karekwa, both equally imbued with the enduring aesthetic and material value of women's agency in working for sagali, and simultaneously absorptive of commodity value set by the market economy. The fidelity to cultural values is remarkably stable in interaction with the accelerated flows of cash and manufactured goods incorporated in sagali transactions (Figure 3).

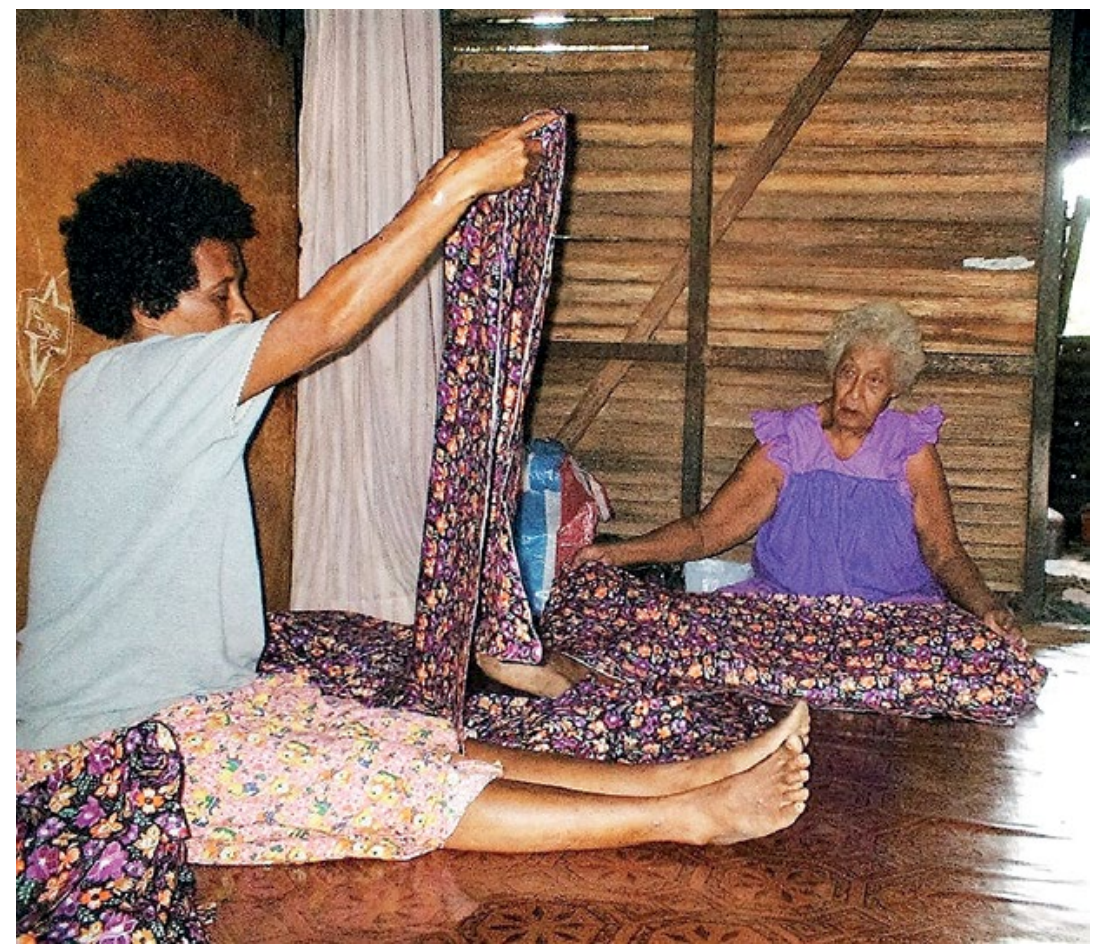

Figure 3. Lucianne Gilbert and the late Sarah Watson prepare pieces of karekwa for sagali, Orabesi village, Kiriwina

Source. Photographed by Katherine Lepani, 9 June 2003 


\section{Material innovations and consumer pleasures}

Like their early missionary ancestors, Trobriand women continue to use their sewing skills to work for sagali. Cloth is highly valued because of its immediate utility in daily life: a simple laplap, or wrap, tied around the waist, or sewn into garments; and household items-sheets, pillowslips, tablecloths, curtains. Young men get pieces of cloth from their mothers and aunties to use for buwala, the obligatory gifts given by men to women after lovemaking, which connect intimate transactions to larger networks of exchange (Lepani 2012: 112-18). The bright colours and bold tropical designs of the bolts of fabric purchased for sagali animate the intertwining flows of exchange relations and enliven the template of the social landscape, weaving their way into the materiality of everyday life. The selection and precirculation of bolts of fabric have become part of the patterning and coding of sagali performance; ensembles of women collectively assign specific colours and designs to different generations of clanswomen taking part, and to signify clan and village affiliations as well as ways in which participants are related to the deceased.

The integral value of cloth in doba distributions is most prominently conveyed by sepwana, the hallmark of sagali. Sepwana signifies the mourning skirts made and worn by the clanswomen of the deceased's father and spouse (if the deceased was married), who in turn are the primary recipients of sagali transactions. Sepwana also takes the stately form of piles of freshly made bundles of doba, numbering in the hundreds, which are carefully arranged and balanced on flat woven baskets (Figure 4). Made by the deceased's clanswomen to acknowledge and compensate the principal mourners, the piles of fresh bundles measure at least 1 metre in height and are topped with new fibre skirts, pieces of cloth and cash. The number of sepwana piles at sagali is optional but minimally there must be two to represent the primary exchange relations between the deceased's clan and the clans of the deceased's father and spouse. Additional sepwana are made in the name of close friends of the deceased, favourite nephews or nieces, or brothers who work hard for their sisters to acquire doba for sagali. 


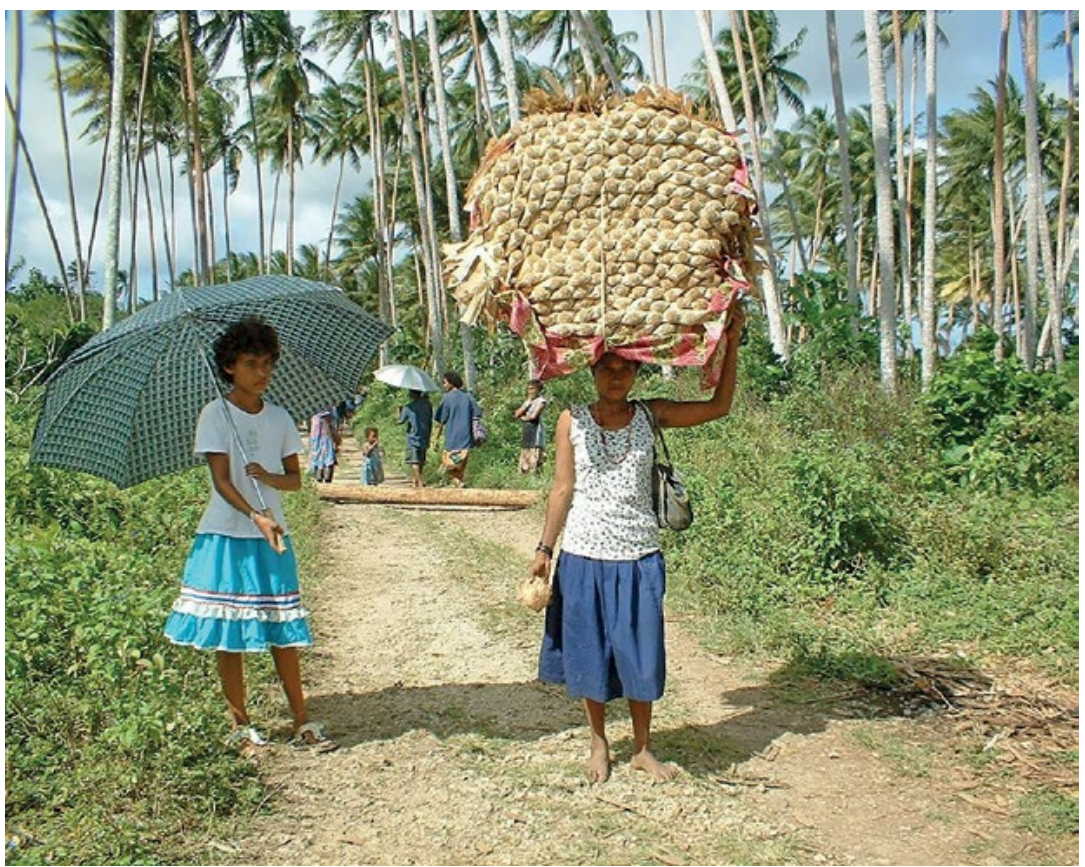

Figure 4. Carrying sepwana to sagali on the road to Kwemtula village, Kiriwina

Source. Photographed by Katherine Lepani, 18 July 2003

The women who assemble the sepwana piles and carry them to sagali on their heads wear new skirts, which are also referred to as sepwana. These skirts are no longer woven with banana fibres as in the past, but now are sewn with cotton material, and their production involves vibrant skill and creativity-full swinging skirts with contrasting coloured panels and layers, adorned with rickrack, ribbon and lace. Innovations are the source of mirth and playful engagement with modern fashion, but they can also be serious reflections on changing gender practices. In 2003, I attended a sagali where the women who assembled the sepwana piles collectively decided to wear trousers instead of skirts; they fashioned them out of sagali fabric plus purchased some at the newly opened second-hand clothing store on the island. In special tribute to the deceased, a young woman who had a successful career as a primary school principal, this innovation was a powerful statement about women's agency in the modern world. 
Sagali distributions of bundles, cloth and cash, carried out methodically over long stretches of time, become aesthetically heightened during sepwana presentations and then culminate in the delights of deli, the most extravagant and plentiful site of exchange. Deli is the last series of distributions in sagali and is a complementary follow-up to sepwana to inspire ongoing reciprocal support in future sagali. The Trobriand word deli is the preposition 'with', and it also means to 'follow behind' or 'line up one after another'. Deli items are paraded in long lines to the recipients, who are the chief mourners from the clans of the deceased's father and spouse. This is the high point in sagali when the mourners are 'cleaned' by ceremoniously removing their black mourning attire and tying freshly made fibre skirts and cloth material around their hips, fitting them with newly sewn skirts and shirts, and then showering them with a plenitude of manufactured goods. In addition to skirts, clay pots, woven mats and baskets, deli items include an array of practical domestic merchandise such as cooking pots, plates and cups, cutlery, umbrellas, towels, sheets, clothing, bras and underpants. The hallmark of display in deli parades are the poles and cut tree branches festooned with fabric, money and consumer goods. Deli signifies excessive consumption in the true sense of feasting, and pragmatic investments in the materiality of the modern world, providing recipients periodic access to goods otherwise difficult to attain. The practice of deli achieves a dazzling effect of valuation that merges women's productive agency and matrilineal regeneration with the monetary economy. This concentrated site of material consumerism is where sagali has undergone its most dramatic transformations to date, and it might prove to be the site that eclipses doba bundles as markers of indebtedness, categorically transforming the materiality of exchange into commercial products of consumption. Deli is likely to be the site most fraught with moral debate as Trobrianders face future decisions about embodied capacity, productivity and value, and the consequences of emerging economic inequalities and financial burdens on livelihoods.

In August 2010, I participated in the sagali for my mother-in-law, who had passed away peacefully in January 2010 at the age of 81 years. The sagali was a massive event in her residential village of Orabesi. With proceedings held over three days, the event involved nearly 1,000 participants, including people who travelled home to the Trobriands from elsewhere in Papua New Guinea and overseas. The considerable financial resources put into the feast by my husband Charles and members of his clan included the purchase of over 40 bolts of fabric from a wholesale store in Alotau, 
which were shipped to the Trobriands on a chartered cargo boat. Several of Charles's dala sisters and I, and our daughters and nieces, spent a day measuring and cutting the bolts of fabric into 2-metre and 5-metre lengths, and pile sorting them by colour, pattern and size in preparation for distribution. Such material largess might be evaluated by some observers as an inflationary distortion of women's wealth, where monetary inputs turn gifts into commodities and overshadow women's productive agency in working for sagali. Yet the scale and symbolic 'density' of the material objects of exchange (Weiner 1994) reflected the flows of support for the event and met the collective expectation of what Charles should be able to mobilise as sponsor of the sagali, or toliu'ula, acting on behalf of his matriline. My personal contribution as the daughter-in-law of the deceased was a further variation of the forms doba takes; in tribute to my mother-in-law's renown as a seamstress, I topped each of the 16 sepwana piles with sewing kits.

\section{Material conversions, adjustments of scale and translocality}

Trobrianders living in other locations in PNG and overseas express a strong sense of obligation and desire to participate in sagali. Such motivation attests to the importance of sagali as an integrative practice in social and economic life, and its essential role in regenerating matrilineal identity. The enterprising agency of a young single mother of three living in Port Moresby exemplifies the translocality of working for sagali, the shifting forms of doba, and the transactional pathways that turn commodities into gifts (Gregory 1997: 55). Born and raised in the nation's capital, the young woman's mother is from Central Province and her father was from the Trobriands. Several months after her father died in 2012, she text messaged me in Australia to say she was looking for help to start up a small food stall in the neighbourhood where she lives, to sell breakfast to public servants on their way to work. She appealed to me for support in the form of a cash contribution to help with initial expenses. She texted that she was ready to 'start work for my father's sagali' and intended to turn the anticipated income into bolts of fabric to take with her when she travelled to the Trobriands for the feast later that year, which then she would put into circulation to support the women of her father's dala, the organisers of the sagali. As the daughter of the deceased she was a principal mourner and a primary recipient of copious amounts of doba during the 
sagali distributions, yet she orientated her active participation towards working for her father's clan. Her contribution assumed a material form commensurate to the resources she was able to mobilise through her own labour-not bundles of dried banana leaves but cloth. The conversion was multiple: a gift of cash turned into commodity, turned back into cash and then commodity again, and ultimately turned into gift in sagali distributions. Her entrepreneurial initiative could be viewed as a form of fundraising, an enterprise that involved generating cash resources through the mobilisation of social relations. But central to her endeavour were the performative effects of her labour; a public reckoning of her personal capacity, on display and directed toward relational value by acting with others in mind.

The lived experience of increased engagement with the monetary economy is a transformative process, whether practised through distinctly cultural forms or through changing livelihood strategies and consumption patterns; whether one is involved in the fluctuating cycles and scales of exchange in a rural village or dependent on regular flows of cash income in an urban context. Material conversions are increasingly modifying the forms and valuations of relations of exchange. The young woman's enterprising agency in the urban informal sector, strategising her options as an unemployed single mother with a translocal objective in mind, poses important questions for policies that seek to promote gender equality and women's empowerment through increased economic participation. Interventions and programmatic efforts aimed at expanding opportunities for women as economic agents and consumers, primarily in formal-sector employment, must be attentive to the informal arena where women's creative and innovative practices are directed at upholding social relations, and where indebtedness to others is valued as a productive site of relational agency (see Jolly et al. 2015). Indeed, as the young woman's actions suggest, indebtedness can be understood as a form of empowerment. It is important to recognise the ways in which women negotiate their economic options at the collective level, strategically activating obligations and channelling their monetary resources towards others, even as they strive to carve out more autonomy in their individual lives (see Macintyre 2011). What many women seek is not economic independence per se but economic opportunities to fulfil social obligations and make stronger contributions to collective wellbeing and social cohesion. 
The material production of objects for sagali-banana fibre and cotton skirts, woven mats and hand baskets—is comparative to the extraordinarily vibrant and creative bilum and meri blouse craft practised by women elsewhere in Papua New Guinea. Such products of labour carry multiple values and are highly convertible depending on how they get put into circulation and transacted. But they represent a vibrant dimension of gendered practice in the creative industry sector and beyond (see Teaiwa 2007), and are important indicators for evaluating and valuing women's economic productivity and wealth.

\section{Material durability}

As an in-law and ethnographic researcher, I have been witness to and participant in numerous sagali over a period of nearly 40 years, but my questions about value and transformation in relation to doba and gendered agency have been framed most directly in recent years by how Trobrianders are making sense of HIV (Lepani 2012). Clearly, sagali as the cultural strategy for resolving the disruption of death through regeneration has important implications for how Trobrianders respond to the impact of HIV on their ways of knowing and being. What is patently at stake is people's continued capacity to cope with the demands of social obligation in response to unprecedented disease and death. If such a scenario unfolds, the suspension of sagali obligations is the likely possibility. As a precedent, Trobrianders refer to a malaria epidemic in the mid-1990s, when scores of people died over a short period. In response to the overwhelming loss, the affected communities made a collective agreement to ease sagali obligations. Nonetheless, the ethos of sagali, where people work with others in mind, is a valuable cultural resource for cultivating a positive response to living in the midst of an epidemic and for alleviating the stigma and fear that continues to surround HIV in Papua New Guinea.

And yet other questions about the ethos of sagali come to the fore as well. The collective zeal of increasingly excessive display and consumption in sepwana and deli distributions prompts me to ponder what further transformations might unfold in the Trobriand moral economy, both within and beyond the practice of sagali exchange, especially when the out-of-the-way small coral atolls are subjected to increased environmental and population constraints. Will the effects of climate change impinge on the sustained cultivation of yams and banana trees to the extent that exchange practices and corresponding scales of valuation are irrevocably 
transformed? As the local economy becomes more entwined in wider monetary flows, as consumer desires and the acquisition of material goods become more individualised in interaction with global economic forces and wage labour, and as notions of personhood are reshaped by changing relations with the church and new articulations of Christian faith (see MacCarthy this volume), what might be new transformations of collective exchange practices, and how might gendered assessments of value be revised? When the exchange of one thing for another takes place on a more intimate scale, what might be the transformative material and moral effects on collective social relations? The longing gaze at an item in the shop and the eventual purchase with secretly saved cash; the exchange of a gift between two young lovers, not acquired through larger networks of exchange but purchased directly as a commodity transaction; the 'promising smell' of second-hand clothes, as one of my interlocutors described her sensory pleasure when we walked by the newly opened shop on the island, which then motivated her to bake scones and sell them in her village so she could have extra cash to make a purchase.

And how do people adjust for the burden of scale, especially when cash resources are scarce or have to be pooled through strategic conversions? Translocality has generated simplified forms of practice in urban centres as people cope with the demands of death, where airfares for transporting the deceased's body back home to the village for burial are the major expense. The male organisers of a sagali held in 2013 among Trobrianders living in the national capital determined it would be a modest 'Moresby-style' feast, recognising the financial constraints that face urban wage earners. Intended to be limited to a generic distribution of purchased food staples and cooked market food, plus several pigs and bunches of betel nut, the sagali manifested over the course of the afternoon with generous doba distributions - the women had arrived bearing brand-new plastic clothes baskets abundantly filled with 2-metre lengths of neatly folded fabric.

As a nondurable exchange item, banana leaf bundles continue to represent a deep genealogy of belonging that holds potency for future possibilities, even when transformed by pieces of cloth. A key factor to consider in making a prognosis about the stability of sagali is the enduring imperative, and motivation, to demonstrate dala capacity and vitality through investments of gendered labour. Questions of value and of measuring change should not insist on the durability of a form impenetrable to transformative processes. Investments of personhood in working for sagali ensure the sustainability of value regardless of form. The ephemeral 
bundles of dried banana leaves made by Trobriand women are durable in the Trobriand economy, at least now and for the foreseeable future, because they activate social relations-affiliations, obligations, indebtedness, transactions - through the productive value of labour. Doba offers a form of economic productivity that continues to be recognised and valued in sagali transactions, and in the wider Trobriand economy, for aesthetic purpose and pragmatic action, for reasons of equivalence and reasons of belonging (Figure 5).

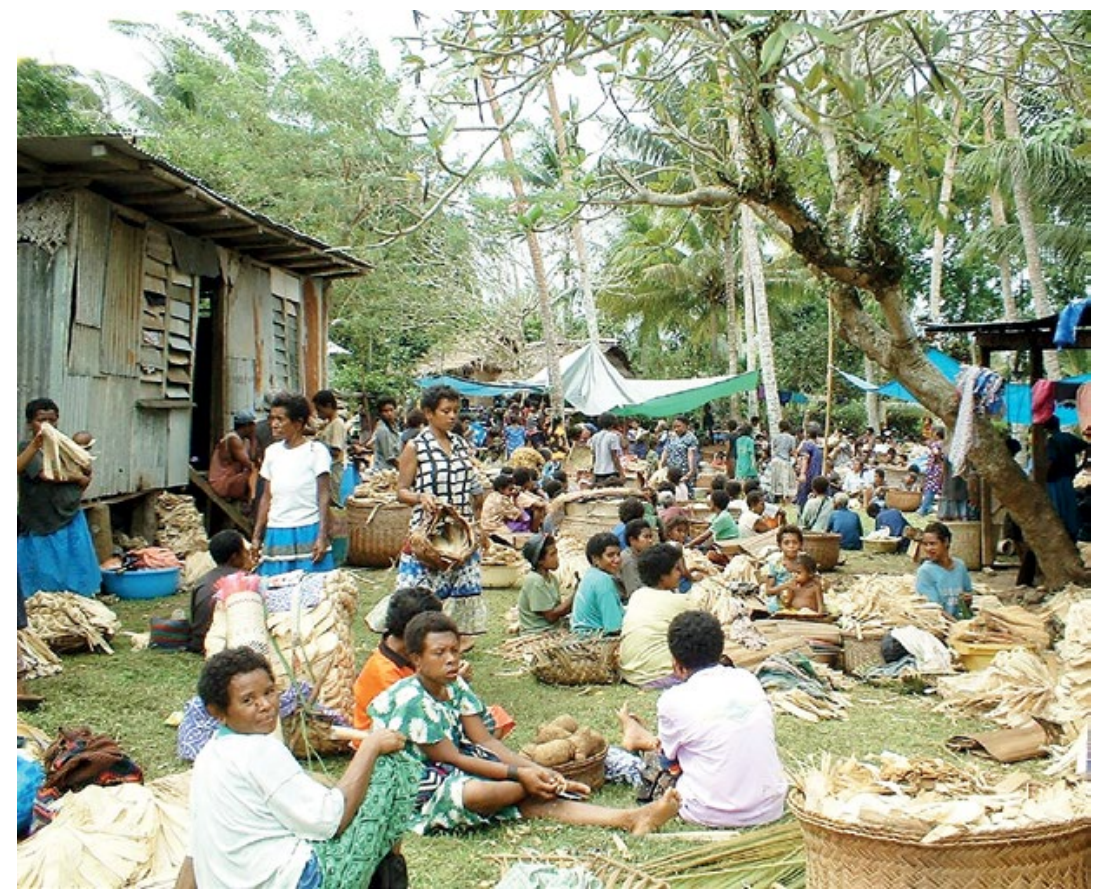

Figure 5. Sagali gathering, Losuia, Kiriwina

Source. Photographed by Katherine Lepani, 19 July 2003

\section{References}

Akerman, Kim. 2001. New Guinea Diaries of the Rev. S.B. Fellows, Vol. 1. 21 July 1891 - 14 October 1893. Hobart, Tasmania: Tasmanian Museum and Art Gallery.

Bashkow, Ira. 2011. 'Old Light on a New Controversy: Alex Rentoul's Account of the Trobriand Women's Sagali. History of Anthropology Newsletter 38(2): 9-18. 
Bromilow, William E. 1893. 'Letter from Mr. Bromilow'. Australasian Methodist Missionary Review, 6 January: 6-7.

Carrier, James G. (ed.). 1992. History and Tradition in Melanesian Anthropology. Berkeley: University of California Press.

Choi, Hyaeweol and Margaret Jolly (eds). 2014. Divine Domesticities: Christian Paradoxes in Asia and the Pacific. Canberra: ANU Press. Online: press.anu.edu.au/publications/divine-domesticities (accessed 31 March 2017).

Connelly, Andrew James. 2007. 'Counting Coconuts: Patrol Reports from the Trobriand Islands, Part I: 1907-1934'. MA thesis. California State University.

Demian, Melissa. 2007. 'Canoe, Mission Boat, Freighter: The Life History of a Melanesia Relationship’. Paideuma 53: 89-109.

Etienne, Mona and Eleanor Burke Leacock (eds). 1980. Women and Colonization: Anthropological Perspectives. New York: J.F. Bergin.

Gregory, Chris A. 1982. Gifts and Commodities. New York: Academic Press.

- 1997. Savage Money: The Anthropology and Politics of Commodity Exchange. Amsterdam: Harwood Academic Publishers.

- 2015. 'Preface to the Second Edition'. In Gifts and Commodities (2nd edition), Chris Gregory, pp. xi-xii. Chicago: HAU Books.

Jolly, Margaret. 1992. 'Banana Leaf Bundles and Skirts: A Pacific Penelope's Web?' In History and Tradition in Melanesian Anthropology, ed. James G. Carrier, pp. 38-63. Berkeley: University of California Press.

- 2014. 'A Saturated History of Christianity and Cloth in Oceania'. In Divine Domesticities: Christian Paradoxes in Asia and the Pacific, ed. Hyaeweol Choi and Margaret Jolly, pp. 429-454. Canberra: ANU Press. Online: press-files.anu.edu.au/downloads/press/p298891/pdf/ ch162.pdf (accessed 23 January 2017). 
Jolly, Margaret, Helen Lee, Katherine Lepani, Anna Naupa and Michelle Rooney. 2015. Falling through the Net? Gender and Social Protection in the Pacific. Discussion Paper for UN Women New York, Progress of the World's Women, 2015-16. Online: www.unwomen.org/en/digitallibrary/publications/2015/9/dps-gender-and-social-protection-in-thepacific (accessed 11 November 2015).

Lepani, Katherine. 2012. Islands of Risk, Islands of Love: Culture and HIV in the Trobriands. Nashville, TN: Vanderbilt University Press.

Macintyre, Martha. 2011. 'Money Changes Everything: Papua New Guinean Women in the Modern Economy'. In Managing Modernity in the Western Pacific, ed. Mary Patterson and Martha Macintyre, pp. 90-120. St Lucia: University of Queensland Press.

Patterson, Mary and Martha Macintyre (eds). 2011. Managing Modernity in the Western Pacific. St Lucia: University of Queensland Press.

Prisk, Ethel M. 1937. Photographs, Documents. Adelaide: South Australia Museum.

Strathern, Marilyn. 1981. 'Culture in a Netbag: The Manufacture of a Subdiscipline in Anthropology'. Man (n.s.), 16(4): 665-688. DOI: $10.2307 / 2801494$.

Teaiwa, Katerina Martina. 2007. 'On Sinking, Swimming, Floating, Flying and Dancing: The Potential of Cultural Industries in the Pacific Islands'. Pacific Economic Bulletin 22(2): 140-151.

Weiner, Annette B. 1976. Women of Value, Men of Renown: New Perspectives in Trobriand Exchange. Austin: University of Texas Press.

- 1980. 'Stability in Banana Leaves: Colonialism, Economics and Trobriand Women'. In Women and Colonization: Anthropological Perspectives, ed. Mona Etienne and Eleanor Burke Leacock, pp. 270293. New York: J.F. Bergin.

—_ 1994. 'Cultural Difference and the Density of Objects'. American Ethnologist 21(2): 391-403. DOI: 10.1525/ae.1994.21.2.02a00090.

Young, Michael W. 2004. Malinowski: Odyssey of an Anthropologist 1884 1920. New Haven, CT: Yale University Press. 
This text is taken from Sinuous Objects: Revaluing Women's Wealth in the Contemporary Pacific, edited by Anna-Karina Hermkens and Katherine Lepani, published 2017 by ANU Press, The Australian National University, Canberra, Australia. 